\title{
An authoritarian parenting: main predictor in temper tantrum of pre-school children
}

\author{
Rusana $^{1}$, Ida Ariani ${ }^{2}$, Erna Sari ${ }^{3}$ \\ 1,2,3 Sekolah Tinggi Ilmu Kesehatan Al-Irsyad Al-Islamiyyah Cilacap
}

\begin{tabular}{l} 
ARTICLE INFORMATION \\
\hline Article history: \\
Received: August 9, 2020 \\
Revised: August 20, 2020 \\
Accepted: August 30, 2020 \\
\hline
\end{tabular}

\section{Keywords:}

Children, parenting, parents, preschool, temper tantrums

\begin{abstract}
Temper tantrum is an emotional condition related to the behavior of preschool children. Tantrums will be problematic if it's excessive and even injurious behavior. Several factors caused tantrums such as physiological, psychological, parental and environmental factors. The aim of this study was to analyze the dominant factors between parental factors (parenting, communication, occupation and gender), child factors (gender, education level) and family environmental factors (number of children under five, families living at home) with temper tantrums for pre-school children. . Analytical survey research and cross sectional design. The sample size was 120 parents and pre-school children using cluster random sampling technique. Bivariate analysis used the chi square test, while multivariate analysis used multiple logistic regression. The results showed that the parenting style was the main predictor related to the temper tantrums of preschool children $(\mathrm{pv}=$ 0,001 ) with an $\mathrm{OR}=14.879$ controlled by variables of occupation and families live at home.In conclusion authoritarian parenting style causes temper tantrums 14.8 times higher than democratic parenting in pre-school children.
\end{abstract}

This work is licensed under a Creative Commons Attribution 4.0 International License.

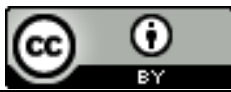

Corresponding Author:

Rusana,

Sekolah Tinggi Ilmu Kesehatan Al-Irsyad Al-Islamiyyah Cilacap

Email: idaariani1234@gmail.com

\section{INTRODUCTION}

Preschool children are children aged 3-5 years [1]. Preschool children have a very egocentric nature, curiosity, oppose or fight, show autonomy and independence and are strengthened by the ability of high physical mobility / activity and greater cognitive in exploring the environment [2]. Based on the United Nations Children's Fund (UNICEF) 2019 data report that differences between regions indicate inequality, there are half of Indonesian children who experience development and welfare constraints, even though children do not always come from households that are classified as "poor" by conventional financial standard. Children who are below the poverty line in Central Java province are $15 \%$ or 1.5 million [3]. These data indicate that children are at risk of experiencing disruptions in the development process, including emotional development of children, which can reduce the quality of children's resources.

Common emotional characteristics of children include anger, fear, jealousy, curiosity, jealousy, joy, sadness, affection. Existing negative behaviors such as stomping, breaking things, whining, crying, screaming with all his might, the child will show ego and begin to grow self-power and temper tantrum [4]. Temper tantrums are an emotional condition in the form of behavioral problems commonly experienced by preschooler [5]. The results of the Northwestern Feinberg study, based on a survey of nearly 1,500 parents, showed that $84 \%$ of 2-5 year olds expressed frustration with tantrums in the past month, and $8.6 \%$ of them had daily tantrum [6].There were 23 to $83 \%$ pre-schoolers about 2-4 years who had temper tantrum with in a year in Indonesia. Tantrums are also a problem when they appear with a frequency, intensity and time that is relatively more than what usually occurs in children, followed by out-of-control behavior such as kicking or hitting parents or other adult [7]. 
The factors that cause children's temper tantrums are conflict with parents, the most common conflicts are conflicts regarding food and eating $(16.7 \%)$, conflicts due to putting children in a stroller, high chairs for babies, seats in cars, and so on (11.6\%), conflicts over wearing clothes $(10.8 \%)$. The results showed that there was a relationship between parenting styles and environmental factors with the incidence of temper tantrums in preschoolers $(\mathrm{pv}=0.001)$ [8]. In addition, the causes of tantrums in children are physiological factors (such as tiredness, hunger or illness), psychological factors (such as children experiencing failure, and parents who are too demanding on their children according to their parents' expectations, the child feels stressed or insecure), parental factors (such as patterns. care and communication, the attitude of parents who tend to criticize) and environmental factors (in the form of family or home environment, especially when there are many guests or there are more than two adults and the environment outside the home) [9]

The results of research conducted showed that there was a relationship between parenting styles and the incidence of temper tantrums in preschool children in Ngemplak Bawen ( $\mathrm{pv}=0.000)$ [10] The results of other studies showed that there was a relationship between parenting styles and the incidence of temper tantrums in preschool children $(\mathrm{p}=0.001)$. The pattern of communication in the also affects the development incidence of children's temper tantrums [11]. The results of research shows that there is a significant relationship between communication patterns and the incidence of temper tantrums in preschool children. Parents who apply ineffective communication patterns are 3.2 times more likely to cause temper tantrums than parents who apply effective communication pattern [12]. The application of ineffective communication patterns in the family is at risk of causing the incidence of children with temper tantrums to be higher than that of parents who implement effective communication [13].

The number of children aged 0-14 years is $24.35 \%$ of the total population of Central Java. The data results of the Central Bureau of Statistics of Cilacap Regency in 2017 showed that the number of children ages 0-4 is 66,541 and ages 5-9 are 78,448. Active Posyandu in Central Java Province in 2017 amounted to 66.3\% of the total number of posyandu, which were 48.8915. In 2017 there were 2,155 active posyandu in Cilacap Regency and 113,559 children under five visited, while in 2018 there were 2,170 posyandu and 130,679 toddlers visiting. Toddler visit data consisted of infants and toddlers from 0 months to 60 months, including 301 toddlers and 338 preschoolers. The number of pre-school children is one of the largest compared to the others. Pre-school age is an age that is prone to non-adaptive temper tantrums.

\section{RESEARCH METHOD}

The purpose of this study was to analyze the dominant factors between parent, child and family environment factors with temper tantrums in pre-school age children. This research is a quantitative study with analytic survey design using cross sectional data collection design. Research sites at 10 posyandu in Karang Talun Village. Sampal size was 120 parents and 120 pre-school children (aged 3-5 years) with cluster sampling technique. The criteria for the inclusion of children who come to the posyandu are healthy, the first child and with their parents, are able to communicate.

\subsection{The variable, intruments and measurements}

The variables in this study were parenting styles, parent communication, parent's occupation, gender of parents and children, level of education of children, number of children under five in the family, families living at home and temper tantrums. The instrument used was a questionnaire about parenting using 24 statements, 16 questions of parent communication,parent's occupation, gender of parents and children, education level with two questions whether attending PAUD / kindergarten or not, number of children under five in the family, family living house other than the nuclear family. The temper tantrum variable consists of 33 statements with a Likert scale with 4 alternatives.

\subsection{Data Analysis}

Data analyzed by a bivariate analysis using chi square test and multivariate with multiple logistic regressions.

\subsection{Ethical consideration}

The study respondents were interviewed at the posyandu and previously there was informed consent. All procedures are in accordance with research ethics but this research did not require ethical approval.

\section{RESULTS AND DISCUSSIONS}

The age of the parents is the productive age, while the age of preschoolers is 3-5 years old. The majority of parents met are woman where their latest education was limited to highschool, still live with their parents and work as domestic helpers. The majority of boys, who have not yet attended PAUD / TK, have 1 child. The 
majority of parenting styles are democratic, functional communication, preschool age respondents experienced temper tantrums in the low category (table 1).

The results of the chi square test showed that the factors of parenting and gender had a significant relationship with temper tantru $(p=0.001 ; p=0.029)$ (table 2). The results of the bivariate selection included in the modeling were the gender of the parents, occupation, parenting, communication and the family who lived at home $(\mathrm{p}<0.25)$. Table 3 is the final result of the multiple logistic regression test, parenting style is the most dominant factor associated with temper tantrums after being controlled with variables of work and family who live at home $(\mathrm{OR}=14.879)$.

Table 1. Demographic profiles of respondents: parents and children

\begin{tabular}{|c|c|c|}
\hline Characteristics/ Univariate & Parents & Children \\
\hline \multicolumn{3}{|l|}{ Age (years): } \\
\hline Mean & $30,95(5,904)$ & $3,82(0,722)$ \\
\hline Min-Max & $22-46$ & $3-5$ \\
\hline \multicolumn{3}{|l|}{ Gender } \\
\hline Female: f (\%) & $114(95 \%)$ & $55(45.8 \%)$ \\
\hline Male: $\mathrm{f}(\%)$ & $65(5 \%)$ & $65(54.2 \%)$ \\
\hline \multicolumn{3}{|l|}{ Education } \\
\hline No schooling: f (\%) & & $80(66.7 \%)$ \\
\hline Kinder garten: f $(\%)$ & & $40(33.3 \%)$ \\
\hline Elementary school: f (\%) & $15(12.5 \%)$ & \\
\hline Junior high school: f (\%) & $26(21.7 \%)$ & \\
\hline Senior high school: f $(\%)$ & $67(55.8 \%)$ & \\
\hline University: f (\%) & $12(10 \%)$ & \\
\hline \multicolumn{3}{|l|}{ Occupation } \\
\hline Houswife: f (\%) & $96(80 \%)$ & \\
\hline Non houswife: $\mathrm{f}(\%)$ & $24(20 \%)$ & \\
\hline \multicolumn{3}{|l|}{ The number of children under five } \\
\hline One: $\mathrm{f}(\%)$ & $26(21.7 \%)$ & \\
\hline \multicolumn{3}{|l|}{ Two: f $(\%)$} \\
\hline \multicolumn{3}{|l|}{ families live at home: } \\
\hline Nothing: f $(\%)$ & $70(58.3 \%)$ & \\
\hline $\begin{array}{l}\text { There are (grandparents/ aunty uncle): } \\
\mathrm{f}(\%)\end{array}$ & $50(41.7 \%)$ & \\
\hline \multicolumn{3}{|l|}{ Parenting style: } \\
\hline Democratic: f (\%) & $107(89.2 \%)$ & \\
\hline Autoriter: f (\%) & $13(10.8 \%)$ & \\
\hline \multicolumn{3}{|l|}{ Communication: } \\
\hline Funsional: f (\%) & $27(22.5 \%)$ & \\
\hline Disfungsional: f (\%) & $93(77.5 \%)$ & \\
\hline \multicolumn{3}{|l|}{ Temper tantrum classification: } \\
\hline Low: f $(\%)$ & $62(51.7 \%)$ & \\
\hline Moderate: f $(\%)$ & $58(48.3 \%)$ & \\
\hline
\end{tabular}

Table 2. Analysis of variables the relationship between Parenting and Temper Tantrums Preschool Age Children

\begin{tabular}{|c|c|c|c|c|c|c|c|c|}
\hline \multirow{3}{*}{ Variables } & \multicolumn{4}{|c|}{$\begin{array}{c}\text { Tempertantrum } \\
\text { classification }\end{array}$} & \multirow{2}{*}{\multicolumn{2}{|c|}{ Total }} & \multirow{3}{*}{$\begin{array}{c}\text { OR } \\
(95 \% \mathrm{CI})\end{array}$} & \multirow{3}{*}{ p-value } \\
\hline & \multicolumn{2}{|c|}{ Low } & \multicolumn{2}{|c|}{ Moderate } & & & & \\
\hline & $\mathbf{f}$ & $\%$ & $\mathbf{f}$ & $\%$ & f & $\%$ & & \\
\hline \multicolumn{9}{|l|}{ Gender preschool } \\
\hline female & 26 & 47,3 & 29 & 52,7 & 55 & 100 & \multirow{2}{*}{1,385} & \multirow{2}{*}{0,376} \\
\hline male & 36 & 55,4 & 29 & 44,6 & 65 & 100 & & \\
\hline \multicolumn{9}{|l|}{ Education preschool } \\
\hline No schooling & 40 & 50 & 40 & 50 & 80 & 100 & \multirow[t]{2}{*}{1,222} & \multirow[t]{2}{*}{0,605} \\
\hline Kinder Garten & 22 & 55 & 18 & 45 & 40 & 100 & & \\
\hline \multicolumn{9}{|l|}{ Occupation } \\
\hline Houswife & 53 & 43 & 55,2 & 43 & 96 & 100 & \multirow[t]{2}{*}{2,054} & \multirow[t]{2}{*}{0,120} \\
\hline non housewife & 9 & 5 & 37,5 & 15 & 24 & 100 & & \\
\hline
\end{tabular}




\begin{tabular}{|c|c|c|c|c|c|c|c|c|}
\hline \multicolumn{9}{|l|}{$\begin{array}{l}\text { The number of children } \\
\text { under five vears old in the }\end{array}$} \\
\hline One & 13 & 50 & 13 & 50 & 26 & 100 & \multirow{2}{*}{1,089} & \multirow{2}{*}{0,848} \\
\hline Two & & & & & & & & \\
\hline \multicolumn{9}{|l|}{ Families live at home } \\
\hline Nothing & & & & & & & \multirow{3}{*}{0,561} & \multirow{3}{*}{0,123} \\
\hline There are (grandparents/ & 32 & 45,7 & 38 & 54,3 & 70 & 100 & & \\
\hline aunty uncle) & 30 & 60 & 20 & 40 & 50 & 100 & & \\
\hline \multicolumn{9}{|l|}{ Parenting style } \\
\hline Democratic & 61 & 57,0 & 46 & 43,0 & 107 & 100 & \multirow[t]{2}{*}{15,913} & \multirow[t]{2}{*}{0,001} \\
\hline autoriter & 1 & 7,7 & 12 & 92,3 & 13 & 100 & & \\
\hline \multicolumn{9}{|l|}{ Communication } \\
\hline Funsional & 10 & 37,0 & 17 & 63,0 & 27 & 100 & \multirow[t]{2}{*}{0,464} & \multirow[t]{2}{*}{0,084} \\
\hline Disfungsional & 52 & 55,9 & 41 & 44,1 & 93 & 100 & & \\
\hline
\end{tabular}

Table 3. Final Multivariate Modeling Results

\begin{tabular}{lcccc}
\hline Variable & B & Ward & p-value & OR (95\% CI) \\
\hline Employment & 1,739 & 1.226 & .268 & $.653-4.631$ \\
Families live at home & 0,633 & 1.307 & .253 & $289-1.386$ \\
Parenting style & 14.879 & 6.444 & .011 & $1.850-119.664$ \\
\hline
\end{tabular}

The age of parents of preschool aged children in KarangTalun area, Cilacap Regency is included in the productive age category, that was between 22-46 years with an average (mean) of 30.95 and the most at 27 years of age as many as 12 respondents $(10.0 \%)$. This is possible because many parents who work to migrate first and only get married at a mature age. This result is in line with research that the average age of parents of preschool children is in the 30-39 year age group[20]. Chaeraini's research also supports the results of this study, that the average age of parents of preschool children is between 31-40 years [14]. The results of this study indicate that most of the ages of parents range from early adulthood or early adulthood. Hurlock states that early or early adulthood is in the age range of 20-40 years. In Indonesia, the initial limit for adulthood is 21 years. Early adulthood is a period of early adjustment to life patterns and new social expectations [15]. In addition, this period is also a period of productive age for women, where the age range of 30-40 years is a mature position in taking care of the household and meeting the needs of children which include love, foster care and nurturing [16].

Most of the sexes of parents of preschool age children were female, as many as 114 respondents (95.0\%). The gender of parents of children aged 3-5 years that were met were all women, which were 45 respondents $(100 \%)$. Other research shows that the most common gender of parents is female, as many as 30 respondents $(100 \%)$. The child grows and develops his abilities by seeing and imitating the mother, because in most families the mother often performs the main care duties. The results of this study are in line that with the Chi-Square test, it was found that there was a relationship between parenting styles and temper tantrums in preschool children (3-5 years) in PAUD Pelangi II Kepel Village, Kare District, regency. Madiun ( $p v=0.001$; $\alpha=0.05)$, with a moderate level of closeness between variables $(r=0.501)$. Parents who use democratic parenting cause a low intensity of temper tantrums, while parents who use authoritarian or permissive parenting cause intensity of temper tantrums which tend to increase [17].

Previous research conducted on emotional maturity in young married men and women, showed that the highest emotional maturity was in women aged 24 years, while in men, the highest emotional maturity was owned by men aged 23 years. This shows that couples who marry young in their teens still have to learn to control their emotions in facing all the responsibilities and problems in the family. The role of the majority of parents is good, because they are in the age range of 30-40 years or are in a mature or final position in managing the household and meeting the needs of children which include love, foster care and teasing [18]. Even though there are clear boundaries between types of parenting, in reality parents find it difficult to use just one parenting style in educating their children. There are no parents who only use one parenting style in educating and caring for their children. This means that there is a tendency that there is no pure parenting style, but parents can apply the three types of parenting according to the situation and conditions that occur. A parenting pattern that is full of love, affection and warmth, but at the same time creates clear boundaries and structures is important to reduce and overcome children's temper tantrums.

The results of this study are in line with the theory that fathers' involvement in parenting is very good for children's development. Various studies have shown that fathers who are involved in parenting and play activities with children under five have children with high IQ scores, language capacity, cognitive abilities, 
social skills, social skills, and good behavior [19]. This means that the gender of the parents did not affect the temper tantrum in children, because the parenting process is carried out between husband and wife. Social support from family members especially husband or father, also influences the children process. This will reduce the stress of parenting from the wife, so they can share feelings, offer assistance in child care.

However, this is different from the statement that the majority of people closest to the child are mothers. Father and mother have an equally important role, but mothers are more likely to have a bond with their children from the womb to birth and care for them[18]. The variables significantly related to the temper tantrums of preschoolers were parenting and the gender of the parents. The researcher included 3 other variables because substantially and the results of the biavariate selection had $p<0.25$, namely the work of parents, communication and family living at home. The parenting style variable is the most dominant factor related to the temper tantrum of preschool children in KarangTalun Village, because the OR value is the largest. Parents with authoritarian parenting will have a 14,879 times higher chance of causing the temper tantrums of preschool children compared to the application of democratic parenting, after controlling for the gender variable of the parents. The results of this study are due to the application of parenting patterns that are full of love, affection and warmth, but at the same time creating clear structures and boundaries (democratic parenting), which are important things that can reduce the temper tantrums of preschool children.

There is a relationship between parenting styles and temper tantrums in preschool children (3-5 years) in PAUD Pelangi II, Kepel Village, Kare District, Madiun Regency. Parents who use democratic parenting cause a low intensity of temper tantrums, while parents who use authoritarian or permissive parenting cause intensity of temper tantrums which tend to increase. The lower intensity of children's temper tantrums in children with the application of democratic parenting. The results of this study are also supported by the theory put forward that the parenting style plays a role in causing tantrums, in which the more authoritarian the parents are, the more likely the child will react with anger. The application of parenting that is full of love, affection and warmth, but also creates clear boundaries and structures, has been shown to reduce the intensity of temper tantrums in children. However, it is undeniable that parents can apply the three types of parenting in accordance with the situations and conditions that occur in the care of preschool children.

\section{CONCLUSION}

The parenting style variable is the most dominant factor associated with the temper tantrums of preschool children in KarangTalun, where the application of authoritarian parenting has a 14,879 times higher chance of causing the temper tantrums of preschool children compared to democratic parenting after controlling for the variables of parent and family work. Who live in the same house.The results of this study can have a positive impact on nursing and related units so that they can carry out more monitoring of preschoolaged children in the area. Nurses or health workers can provide health education about temper tantrums and how to overcome them to parents and families.

\section{Acknowledgements}

The author would like to thank the chairman and head of the research and community service unit of STIKES Al-Irsyad Al-Islamiyyah.

\section{REFERENCES}

[1] A. Kaluas, Ismanto and R. Kundre, "Perbedaan Terapi Bermain Puzzle Dan Bercerita Terhadap Kecemasan Anak Usia Prasekolah (3-5 Tahun) Selama Hospitalisasi Di Ruang Anak Rs Tk. Iii. R. W. Mongisidi Manado," Jurnal Keperawatan UNSRAT, vol. 3, no. 2, pp. 11-55, 2019. F. Dinantia and G. Indriati, "Intensitas Perilaku Temper Tantrum," Universitas Riau, Riau, 2017.

[3] GOVT, "Profil Kesehatan Provinsi Jawa Tengah 2017," Dinkes Jateng, vol. 3511351, no. 24, pp. 162, 2017.

[4] T. S. Watson and S. Gebhardt, "Temper Tantrums: Guidelines for Parents and Teachers," Natl. Assoc. Sch.Psychol, pp. 1-4, 2010.

[5] R. J. Fetsch and B. Jacobson, "Children's Anger and Tantrums," no. 10, pp. 13-15, 2013.

[6] L. S. Wakschlag, "Defining the developmental parameters of temper loss in early childhood: im...: EBSCOhost,"," Journal Child Psychol Psychiatry, vol. 53, no. 11, p. 1099-1108, 2012.

[7] Alini and W. Jannah, "Hubungan Pola Asuh Orang Tua dengan Kejadian Temper Tantrum Pada Anak Usia Prasekolah di Kelompok Bermain Permata,," journal universitas pahlawan, vol. 3, no. 2, p. $1-10,2019$.

[8] S. Hartini, F. Hermawan, "Hubungan Pola Asuh Orang Tua Dan Faktor Lingkungan Dengan Kejadian Temper Tantrum Pada Anak Usia Pra Sekolah Di Ra Darul Falah Ngembalrejo Kecamatan 
Bae Kabupaten Kudus Tahun 2012," Jurnal Keperawatan Dan Kesehatan Masyarakat, vol. 2, no. 1, pp. 22-52, 2012.

[9] M. Sukma, R. F. Arifin and F. Putra, "Hubungan antara Komunikasi Orang tua terhadap Anak dengan Temper Tantrum Anak di TK Nurul Hidayah ( The Correlation between Parent's Communitation to Child and Child 's Tempered Tantrum at Nurul Hidayah Kindergarten," vol. 7, no. 2, 2019.

[10] A. Ramadia, "Hubungan Pola Asuh Orang Tua dengan Temper Tantrum Pada Anak Usia Toddler di PAUD Kota Bukittinggi," Menara Ilmu, vol. XII, no. 7, pp. 7-15, 2018.

[11] A. Wulandari, "Pelatihan Komunikasi Efektif untuk Meningkatkan Pengetahuan Ibu dalam Mengatasi Tantrum pada Anak Usia Prasekolah," Universitas Indonesia, Depok, 2013.

[12] P. P. K. WARDANI, "Hubungan Pola Komunikasi," vol. 3, no. 2, pp. 3-7, 2016.

[13] R. Yiw'Wiyouf, A. Ismanto and A. Babakal, "Hubungan Pola Komunikasi Dengan Kejadian Temper Tantrum Pada Anak Usia Pra Sekolah Di Tk Islamic Center Manado," Jurnal Keperawatan UNSRAT, vol. 5, no. 1, pp. 110-265, 2017.

[14] N. Chairini, "Faktor-faktor yang berhubungan dengan stres pengasuhan pada ibu dengan anak usia prasekolah di posyandu kemiri muka," 2013.

[15] S. Syam, "Hubungan Pola Asuh Orang Terhadap Kejadian Temper Tantrum Anak Usia Toddler Di Paud Dewi Kunti Surabaya," Jurnal Promkes, vol. 1, no. 2, pp. 164-169, 2013.

[16] T. Suhartini, "Hubungan Komunikasi Orang Tua dengan Temper Tantrum pada Anak Prasekolah," INSAN CENDEKIA Med, JOMBANG, 2017.

[17] A. Hanura, "Hubungan Pola Asuh Orang Tua dengan Kejadian Temper Tantrum Pada Anak Usia Prasekolah (3-5tahun) di Paud Pelangi II Desa Kepel Kec.Kare Kab. Madiun," Madiun, 2017.

[18] Fakultas Ilmu Pendidikan, "Temper Tantrum Pada Anak Pra Sekolah.," Universitas Negeri Semarang, Semarang, 2013.

[19] J. A. Green, P. G. Whitney and M. Potegal, "Screaming, yelling, whining, and crying: Categorical and intensity differences in vocal expressions of anger and sadness in children's tantrums," Emotion, vol. 11 , no. 5, pp. 1124-1133, 2011. 